\title{
TEPUNG BETE SEBAGAI SUBTITUSI TEPUNG TERIGU PADA KELOMPOK USAHA EKONOMI KREATIF DESA LUMBI - LUMBIA KABUPATEN BANGGAI KEPULAUAN
}

\author{
Haruni Ode ${ }^{1}$, Wiranto Ramlan ${ }^{2}$, Mukhtar Lutfie ${ }^{3}$ \\ ${ }^{1}$ Jurusan Manajemen dan Bisnis, Universitas Muhammadiyah Luwuk \\ ${ }^{2}$ Jurusan Pertanian, Universitas Muhammadiyah Luwuk \\ ${ }^{3}$ Jurusan Teknik, Universitas Muhammadiyah Luwuk
}

Email: umyharun@gmail.com, winartoramlan@yahoo.co.id, mekhtarluwuk09@gmail.com,

\begin{abstract}
Abstrak
Potensi ekonomi berkaitan dengan tanaman jenis umbi-umbian di Banggai Kepulauan sangat tinggi. Hasil pertanian umbi-umbian yang melimpah belum dikelolah dengan baik. Hal ini secara umum berdampak pada rendahnya pendapatan para petani. Mulai dari waktu, income dan penjualan dianggap tidak seimbang dengan hasil yang didapatkan. Jika melihat kebelakang semestinya dengan hasil panen yang melimpah, biaya dan tenaga dikorbankan, waktu menunggu masa panen ternyata tidak bisa menaikkan pendapatan,. Permasalahan ini menjadi dasar dilakukannya pengabdian pada Masyarakat di desa Lumbi - Lumbia Kecamatan Buko Selatan Kabupaten Banggai Kepulauan melalui usaha Pembuatan Tepung Bête. Kegiatan ini lebih fokus kepada pembinaan kepada ibu - ibu rumah tangga yang tergabung dalam kelompok PKK desa. Metode pelaksanaan terdiri dari 3 tahap yaitu: 1. Membentuk, membina serta mengembangkan usaha ekonomi kreatif agar memiliki keterampilan dalam bidang enterpreuner/kewirausahaan dalam memanfaatkan potensi sumber daya pertanian umbi bête menjadi tepung. 2. Pembinaan dan pendampingan pengetahuan manajemen dan penguatan keterampilan mitra untuk menggunakan mesin/alat teknologi sederhana pembuatan tepung bete, 3 Praktek membuat tepung bete secara langsung. Hasil pelaksanaan kegiatan ini antara lain masyarakat mampu mengelola potensi sumber daya pertanian yang melimpah diseluruh wilayah Banggai Kepulauan, para ibu - ibu dalam kelompok mitra menjadi terampil untuk berinovasi. Kreatifitas dan keterampilan ibu-ibu semakin meningkat. Semula membuat penganan/kue yang berbahan utama tepung terigu, kini para Ibu mampu membuat aneka kue menggunakan tepung bête. Pengetahuan manajemen sekaligus keterampilan mitra semakin meningkat dalam menggunakan mesin/alat teknologi sederhana sebagai alternatif untuk pembuatan tepung bete. Diharapkan pembuatan tepung bête akan terus dikembangkan menjadi produk lokal yang unggul sekaligus icon Desa Lumbi - Lumbia Kecamatan Buko Selatan Banggai Kepulauan.
\end{abstract}

Kata kunci: Manajemen, Enterpreuner, Teknologi Sederhana, Subtitusi Tepung 


\section{PENDAHULUAN}

Desa Lumbi - Lumbia berada dibawah lereng pengunungan dan diapit oleh laut yang jaraknya sekitar $2 \mathrm{Km}$, sehingga sangat banyak tanaman buahbuahan yang ada di lingkungan desa tersebut. Jumlah penduduk desa sebanyak 8.027 jiwa, yang terdiri dari 4.014 jiwa laki - laki $(50,01 \%)$, dan perempuan 4.013 jiwa perempuan $(49,99 \%)$, sedangkan jumlah Kepala Keluarga (KK) adalah sebanyak 2.591 KK. (BPS, 2018). Adapun komoditi unggulannya adalah buah kemiri, cengkeh, kelapa, dan coklat. Selain itu ada hasil hutan lainnya berupa buahbuahan dan umbi - umbian yang juga di tanam langsung oleh petani antara lain durian, manggis, singkong, ketela, bête dan ubi banggai.

Secara umum mayoritas pekerjaan penduduk yang ada di Desa Lumbilumbia adalah petani dan nelayan, yang bergerak dibidang pertanian dan perkebunan. Potensi utama Desa Lumbi - Lumbia sangat beragam, namun ada potensi yang tidak kalah penting untuk dikembangkan dan dilestarikan, Salah satunya adalah potensi pengolahan bête menjadi tepung, sakalipun potensi kelapa, coklat, cengkeh, kemiri dan pala merupakan potensi unggulan Desa Lumbi - Lumbia.

Bete merupakan makanan pokok masyarakat sebagai subtitusi beras di Desa Lumbi - Lumbia dan sebagian besar masyarakat yang mendiami daratan Banggai Kepulauan maupun Banggai Laut. Hampir setiap petani menanam bête dikebun mereka, sehingga jumlah bete sangat melimpah. Beberapa kelompok masyarakat kreatif di Desa Lumbi - Lumbia memanfaatkan bete dalam bentuk kripik dan sejenisnya. Sebagian masyarakat memanfaatkan bête sebagai santapan utama pendamping kopi atau teh di pagi atau malam hari. Kondisi ini sudah lama dijalankan oleh masyarakat yang ada di Desa Lumbi - Lumbia, Tim pengabdian membantu para ibu membentuk kelompok yang mampu berkreasi untuk dibina dan dibekali pengetahuan dalam memanfaatkan hasil pertanian agar memiliki nilai ekonomi yang lebih tinggi dan menjanjikan yaitu mengelolah bete dalam berbagai kreatifitas penyediaan makanan siap saji dalam bentuk jajanan. Tim pengabdian mengajarkan para mitra membuat tepung dari bahan baku bete. Tepung Bete/talas bisa dijadikan sebagai bahan subtitusi tepung terigu dalam pembuatan cookies, meskipun kualitasnya masih relatif rendah terutama dari segi rasa dan komposisi gizinya (Welli dan Dian, 2012).

Tujuan utama pelaksanaan kegiatan ini adalah meningkatkan pengetahuan manajemen khususnya manajemen pemasaran. Pemasaran adalah suatu sistem kesuluruhan dari kegiatankegiatan usaha yang ditujukan untuk merencanakan, menentukan harga, mempromosikan dan mendistribusikan barang dan jasa yang dapat memuaskan kebutuhan baik kepada pembeli yang ada maupun pembeli potensial.(Basu dan Hani,2008 : 4).

Pemanfaatan teknologi bagi masyarakat sebagai usaha peningkatan Penggunaan mesin/alat sederhana sebagai alternafit untuk pembuatan tepung bete yang lebih mudah dan bermutu dalam meningkatkan taraf 
DIFUSI

Volume 2, No.1 Januari 2019

hidup masyarakat desa. (Haruni, Ramadhani dan Yusuf, 2018) dalam hal ini dikhususkan bagi masyarakat yang ada di Desa Lumbi - Lumbia Kecamatan Buko Selatan Banggai Kepulauan agar mampu mengelola potensi sumber daya pertanian yang sangat melimpah hamper diseluruh daratan Banggai Kepulauan. Bete dengan nama latin (Colocasia esculenta) sebagian besar orang Indonesia menyebut talas dan Kepulauan Banggai Kepulauan merupakan sentra penghasil bete dengan produksi berkisar 1,2 ton per musim setiap petani dengan masa panen setiap 6 Bulan (Haruni, Ramadhani dan Yusuf, 2018)

Pada dasarnya beberapa ibu rumah tangga yang tidak tergabung dalam kelompok mitra pernah mencoba membuat tepung dari bahan dasar singkong. Namun hasil yang didapat belum menguntungkan karena belum memiliki pengetahuan tentang dalam pembuatan tepung. Berdasarkan pengamatan dan masukan dari sumber informasi diketahui bahwa cara pembuatan tepung sangat kompleks dan memerlukan waktu lama. Pembuatan tepung mula-mula umbi diparut, kemudian dikeringkan dengan menggunakan bantuan sinar matahari dalam waktu 5 sampai 6 hari. Jika matahari cukup panas tepung bisa dikeringkan hanya 2 hari. Cara ini agak rumit dikembangkan untuk skala produksi dan produk kreatifitas, sehingga dalam skala produksi perlu dikembangkan alat pendukung yang lebih modern. Selain dikarenakan tidak memiliki pengetahuan manajemen, mitra juga tidak didukung dengan pengetahuan tentang cara menggunakan alat/teknologi yang memadai. Dengan demikian, perlu ada pembinaan bagi mitra dalam bentuk peningkatan; pengetahuan dan pelatihan keterampilan baik dalam manajemen maupun pelatihan penggunaan alat/teknologi yang sederhana dalam pembuatan tepung bete.

Mengacu kepada uraian diatas maka tim pengabdian menyusun desain kegiatan dengan melihat masalah masalahan utama yang dihadapi oleh masyarakat Desa Lumbi - Lumbia antara lain:

a. Mitra belum mengetahui teknik pembuatan tepung bete dengan benar.

b. Mitra belum memiliki ilmu pengetahuan tentang manajemen teknik pengolahan tepung.

c. Mitra tidak mampu mengoperasikan alat pendukung pembuatan tepung seperti alat parut, alat pemeras/press dan alat penggiling yang lebih modern.

d. Tingginya hasil panen tidak seimbang dengan pendapatan para petani.

Dari permasalahan - permasalahan yang dialami masyarakat di Desa Lumbi - Lumbia Kecamatan Buko Selatan di atas membuka peluang bagi Tim Dosen yang tergabung dalam tim pengabdian Universitas Muhammadiyah Luwuk untuk hadir dalam memberikan sedikit solusi demi menyelesaikan permasalahan yang terjadi. Hal ini sejalan dengan pilar pengabdian kepada masyarakat yang tertuang dalam pancadarma perguruan tinggi Universitas Muhammadiyah Luwuk.

Dalam hal ini kegiatan dilakukan dalam rangka meningkatkan taraf hidup masyarakat dan partisipasi untuk inovasi yang berkalanjutan khususnya 
pada masyarakat yang ada di Desa Lumbi - Lumbia dalam mengelolah potensi sumberdaya pertanian yang tersedia.

\section{METODE}

Metode pelaksanaan yang dilakukan dalam kegiatan ini yaitu memberikan pembinaan, pengetahuan, keterampilan dan pelatihan tentang pembuatan tepung bete sebagai alternative solusi terhadap masalah yang dihadapi mitra. Adapun metode yang dikembangkan dalam pengabdian ini adalah sebagai berikut:

\section{Tahap Persiapan;}

\section{a. Obsevasi dan Sosialisasi Program}

$\begin{gathered}\text { Awalnya tim pengabdian } \\ \text { langsung }\end{gathered}$
melakukan pengamatan pelaksanaan
kelokasi obyek dengan
pengabdian dilanjutkan $\begin{array}{r}\text { dengan } \\ \text { sosialisasi. Dalam kegiatan tersebut }\end{array}$
mitra dan tim pengabdian menemukan
metode yang harus di berikan kepada
mitra dalam kegiatan pengabdian ini
diantaranya melalui penyuluhan dan
pelatihan/praktek langsung. Hal ini
sangat penting terhadap mitra dalam
memberikan informasi terhadap tujuan
program kemitraan ini, sehingga
seluruh anggota mitra memahami
seluruh rangkaian kegiatan Pengabdian
ini. Adapun bentuk yang dilakukan
adalah tatap muka dengan seluruh
anggota yang tergabung dalam
kelompok mitra, kegiatan ini sekaligus
sebagai ajang silaturahmi dan
sosialisasi agenda keterampilan yang
akan dikembangkan.

\section{b. Kesiapan Mitra}

Dalam tahapan ini dilakukan pertemuan antara tim pengabdian dengan mitra, dalam pertemuan ini kelompok mitra diminta mempersiapkan bahan dan alat penunjang yang disediakan oleh tim pengabdian bersama mitra sebagai pendukung pada tahap pelaksanaan kegiatan Pengabdian.

\section{Tahap Pelaksanaan}

a. Penyuluhan dan Pelatihan Teknik Pembuatan Tepung Bete

b. Pembekalan Pengetahuan Tentang Manajemen Teknik dan Metode Pengolahan Tepung.

c. Penyuluhan dan Praktek Pembuatan Tepung Bete dengan Kegiatan Pendampingan.

Kegiatan Pendampingan bertujuan untuk mengevaluasi pengetahuan tenntang membuat tepung bete. Pendampingan dilaksanakan setelah mitra telah mempraktekkan pembuatan tepung yang dibuat.

Mengoperasikan Alat Pendukung berupa Alat Parut, Alat Alat Pemeras/Press Dan Alat Penggiling Sederhana.

\section{Tahap pasca pelaksanaan Pelatihan}

\section{a. Proses pemasaran}

Hasil pembelajaran pada kelompok mitra adalah tepung bête, olehnya itu mitra bersama tim pengabdian melakukan langkah - langkah dalam memasarkan produk tersebt pada tingkat masyarakat luas, modelnya adalah 
DIFUSI

Volume 2, No.1 Januari 2019

menyampaikan pada masyarakat secara langsung dari mulut kemulut, langkah yang tepat adalah produk tepung bête harus dikemas dan diberi label sebagai icon desa

\section{b. Evaluasi}

Kegiatan evaluasi dalam rangka penguatan dari tahapan - tahapan yang sudah dilaksanakan, bila dalam kegiatan - kegiatan sebelumnya terdapat hal penting sehubungan dengan kegiatan pembuatan teknik pembuatan tepung atau penggunaan alat harus segera dibenahi, kelompok mitra melibatkan diri untuk mendapatkan solusi dan kesepakatan bersama. Diharapkan program perencanaan selanjutnya bisa berhasil lebih memuaskan.

\section{c. Pendampingan}

Paling menarik adalah para ibu PKK berharap tindak lanjut dari pembuatan tepung bete kearah yang lebih banyak ide untuk mengaplikasikan kreatifitas

\section{HASIL DAN PEMBAHASAN}

Hasil pelaksanaan program kegiatan Pengabdian pada Masyarakat ini dilaksanakan selama 5 kali dengan rentang waktu yang berbeda - beda dan sebagian besar pelaksanaan kegiatan ini dilaksanakan di Ruang Balai Desa Lumbi - Lumbia Kecamatan Buko Selatan Kabupaten Banggai Kepulauan yang menghasilkan beberapa peningkatan diantaranya adalah sebagai berikut:

\section{Tahap Persiapan}

Kegiatan observasi dilakukan 1 minggu setalah pengumuman judul PKM ini dinyatakan lulus dari Litabmas Ditjen Kemenristek Dikti, sebelum pelaksanaan, kami berharap kerjasama kelompok tim dalam berpartisipasi penuh saat pelaksanaan kegiatan Pengabdian tersebut, selanjutkan tim pengabdian melakukan sosialisasi yang bertempat di rumah ketua kelompok mitra, kegiatan ini dihadiri oleh dosen yang tergabung dalam Pengabdian pada masyakarat dan 2 orang mahasiswa yang sedang menempuh/sedang memprogram mata kuliah pengantar bisnis, dan lainnya adalah semua anggota kelompok mitra usaha kreatif yang sebagian besar dari kelompok ibu PKK di Desa Lumbi - Lumbia Kecamatan Buko Selatan Kabupaten Banggai Kepulauan.

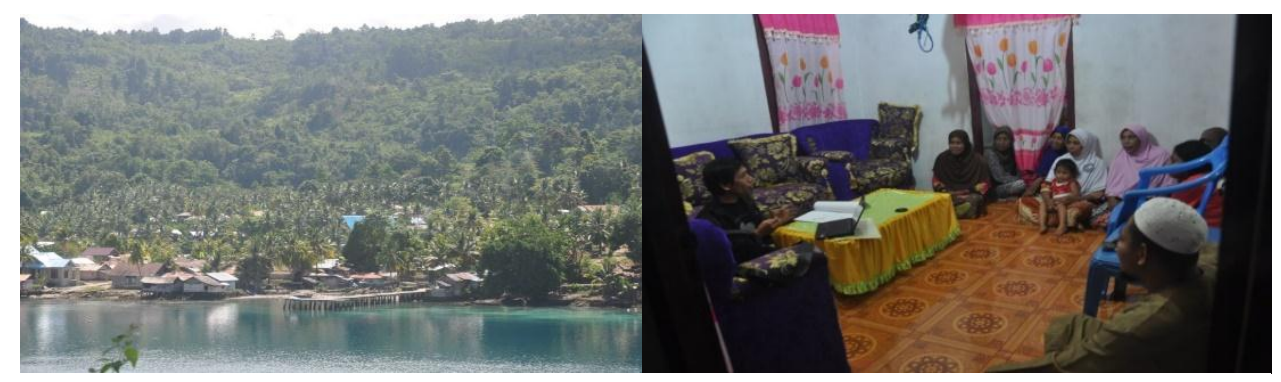

Gambar 1. Observasi dan Sosialisasi Program Pengabdian 


\section{Tahap Pelaksanaan}

\section{a. Penyuluhan dan Pelatihan Teknik Pembuatan Tepung Bete}

Penyuluhan dan pelatihan ini kegiatan Pengabdian pada masyarakat di lakukan dibulan April tahun 2017 kegiatan ini melibatkan semua ibu - ibu PKK desa yang tergabung dalam kelompok mitra, masyarakat serta aparat desa yang ada di Desa Lumbi - Lumbia Kecamatan Buko
Selatan Kabupaten Banggai

Kepulauan. Kegiatan ini berlangsung di ruang Aula Balai desa Lumbi - Lumbia Desa Lumbi Lumbia Kecamatan Buko Selatan Kabupaten Banggai Kepulauan. Adapun rangkaian substansi materi yang diberikan adalah (1) cara menggunakan mesin parut; (2) cara menggunakan mesin press/pemeras; (3) cara menggunakan mesin penepungan.

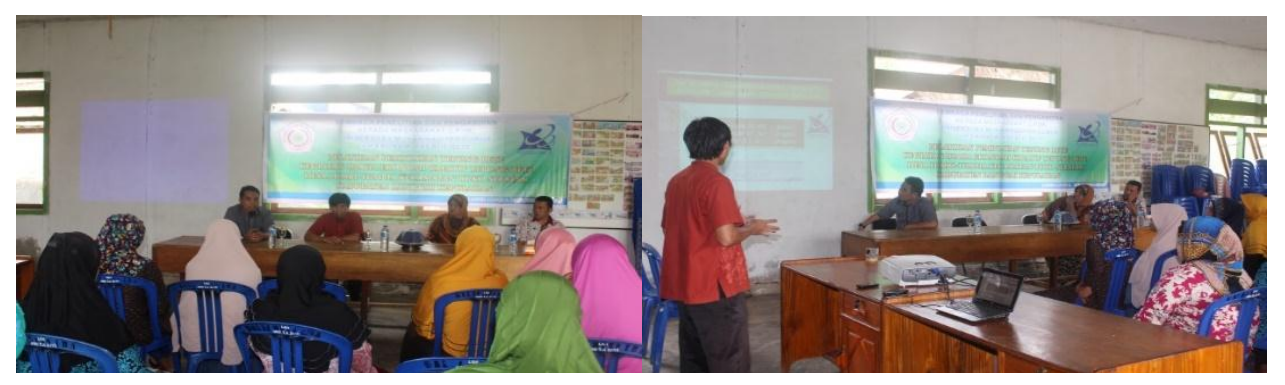

Gambar 2. Penyuluhan dan Pelatihan Teknik Pembuatan Tepung Bete

b. Pembekalan Pengetahuan

Tentang Manajemen Teknik dan Metode Pengolahan Tepung.

Pembekalan pengetahun yang dilakukan oleh salah satu Tim Pengabdian yaitu pengetahuan tentang ilmu manajemen dan pemanfaatan hasil pertanian serta kajian ekonomi dan inovasi. Dalam Pengabdian ini yang terlibat terdiri dari 2 mitra yang berasal dari 2 (Dua) desa yang saling bertetangga, sehingga pada kegiatan yang dilaksanakan ini berlangsung di ruang kantor desa Landonan Kecamatan Buko Selatan Kabupaten Banggai Kepulauan sebagai mitra yang kedua. Adapun rangkaian substansi materi yang diberikan adalah (1) Manajemen pemasaran, (2) Pemanfaatan hasil pertanian dalam kajian ekonomi (3) Cara memasarkan produk. Dalam kegiatan ini diikuti sebanyak 36 orang merupakan gabungan dari dua kelompok mitra dan para mahasiswa. 
DIFUSI

Volume 2, No.1 Januari 2019

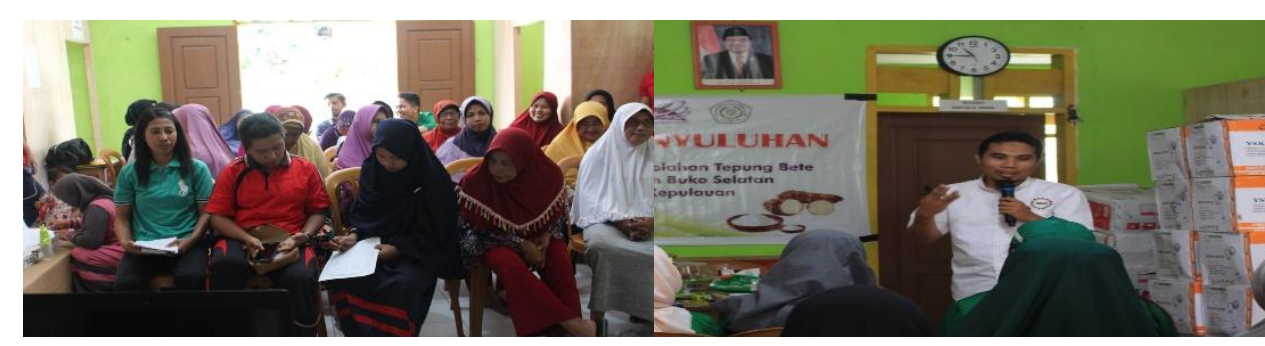

ini

Gambar 3. Pengetahuan Tentang Manajemen Dan Metode Pengolahan

c. Penyuluhan dan Praktek Pembuatan Tepung Bête dengan Mengoperasikan Alat Pendukung berupa Alat Parut, Alat Pemeras/Press Dan Alat Penggiling Sederhana.

\section{1) Penyuluhan}

Dalam kegiatan ini dilakukan tahapan - tahapan, selain hal kegiatan penyuluhan yang dilakukan, ada dua tempat praktek pembuatan tepung bête yaitu di wilayah kampus dan dilokasi Pengabdian adapun tahapannya adalah sebagai berikut : Persiapan dilakukan bertahap dengan langkah - langkah persiapan bahan dan alat / teknologi yang akan digunakan saat proses pembuatan tepung bete, inilah hal utama yang harus dipersiapkan selain sebagai media juga menjadikan pokok pikiran yang dapat mempermudah dan mempercepat proses pembuatan tepung nantinya. Persiapan ini dilakukan setelah kegiatan sosialisasi dan pembekalan. Waktu pelaksanaan 30 menit (13.00-13.30 WITA) di ruang Aula Balai desa Lumbi - Lumbia Desa Kecamatan Buko Selatan Kabupaten Banggai Kepulauan.

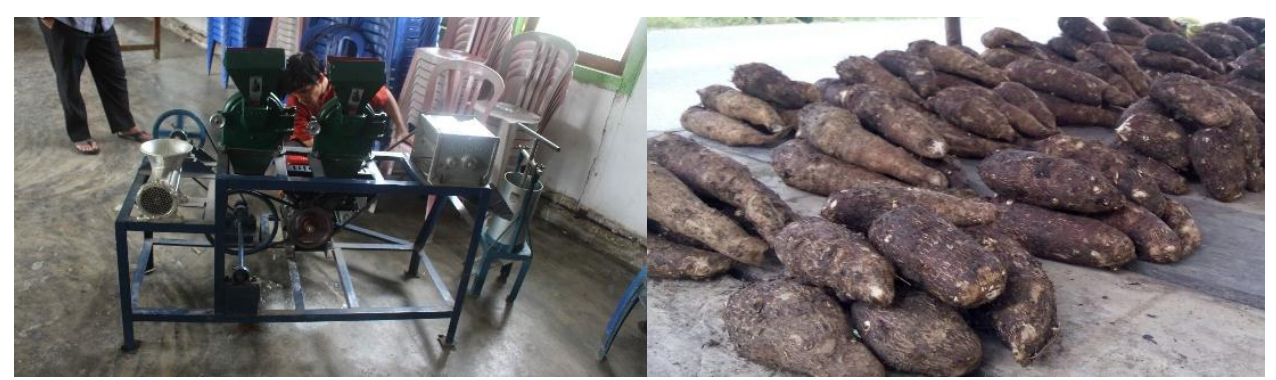

Gambar 4. Alat dan Bahan Tepung Tepung

\section{2) Praktek}

\begin{tabular}{llr}
\multicolumn{1}{c}{ Praktek } & bertujuan untuk \\
mengukur & serta menguji \\
kemampuan & pengetahuan mitra \\
dalam pemahaman atas materi yang
\end{tabular}

sudah disampaikan serta keseriusan kelompok. Praktek dilakukan setelah kegiatan kesiapan bahan dan teknologi pendukung dengan Waktu pelaksanaan selama 4 jam (13.30-16.30 WITA) di ruang Aula 
Balai desa Lumbi - Lumbia Desa Lumbi - Lumbia Kecamatan Buko Selatan Kabupaten Banggai Kepulauan.

Praktek dilaksanakan langsung oleh para ibu - ibu kelompok ekonomi kreatif dan ibu - ibu PKK, peserta sangat banyak dan semua antusias untuk mengikuti semua prosesi dalam kegitan ini, hal ini dibuktikan dengan kedatangan para peserta yang tidak ikut saat pembekalan dan sosilisasi bahkan banyak - bapak ikut terlibat saat proses pembuatan tepung dengan alat/teknologi yang sudah dipersiapkan sebelumnya. tepung yang diharapkan. Dari hasil kegiatan pembuatan tepung bête banyak hal yang pentng untuk dikembangkan.

Praktek dilaksanakan selain ibu - ibu PKK dalam kelompok ekonomi kreatif dan ibu - ibu PKK, juga dilaksanakan oleh para mahasiswa yang sedang menempuh mata kuliah pengantar bisnis

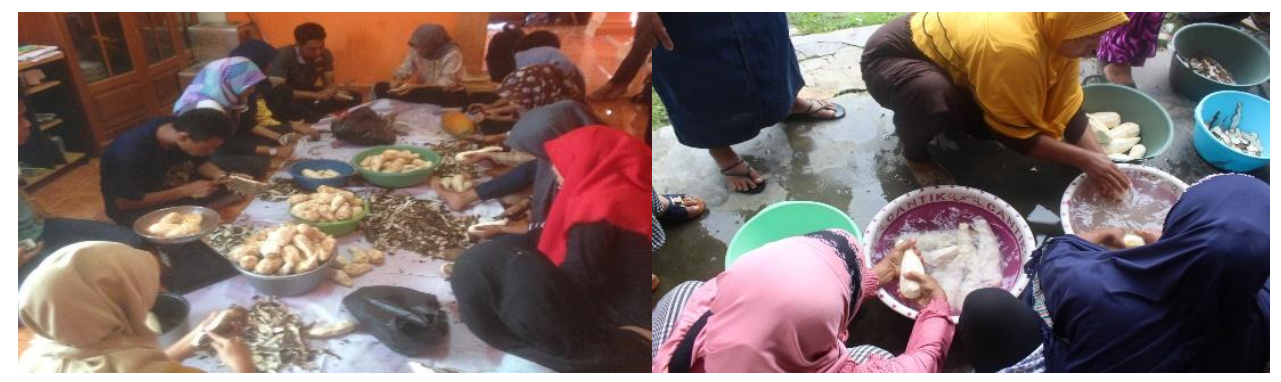

Gambar 5. Umbi Bete dikupas dan Dibersihkan dengan Air

\begin{tabular}{ll}
\multicolumn{1}{c}{ Adapun proses pembuatan } & yang digiling masih harus \\
tepung bete dari proses kupas & bergantung pada cahaya sinar \\
sampai menjadi tepung & matahari, semakin kering hasil \\
menggunakan waktu 5 hari, proses & gilingan maka akan semakin baik \\
pembuatan tepung juga bergantung & kwalitasnya.
\end{tabular}

pada sinar matahari atau suhu panas, hal ini dilakukan selain ingin menghasilkan bentuk tepung yang baik juga proses pengering bete

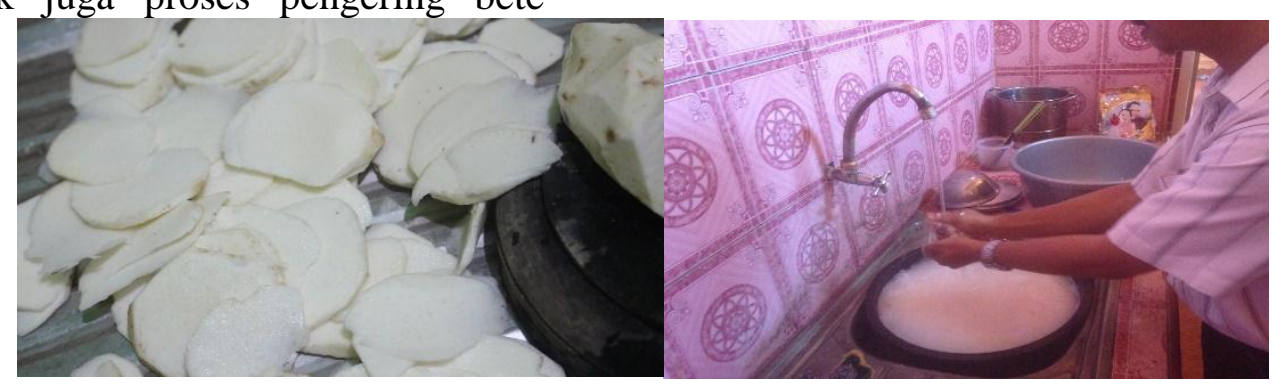

Gambar 6. Umbi diiris tipis, dicuci 
DIFUSI

Volume 2, No.1 Januari 2019

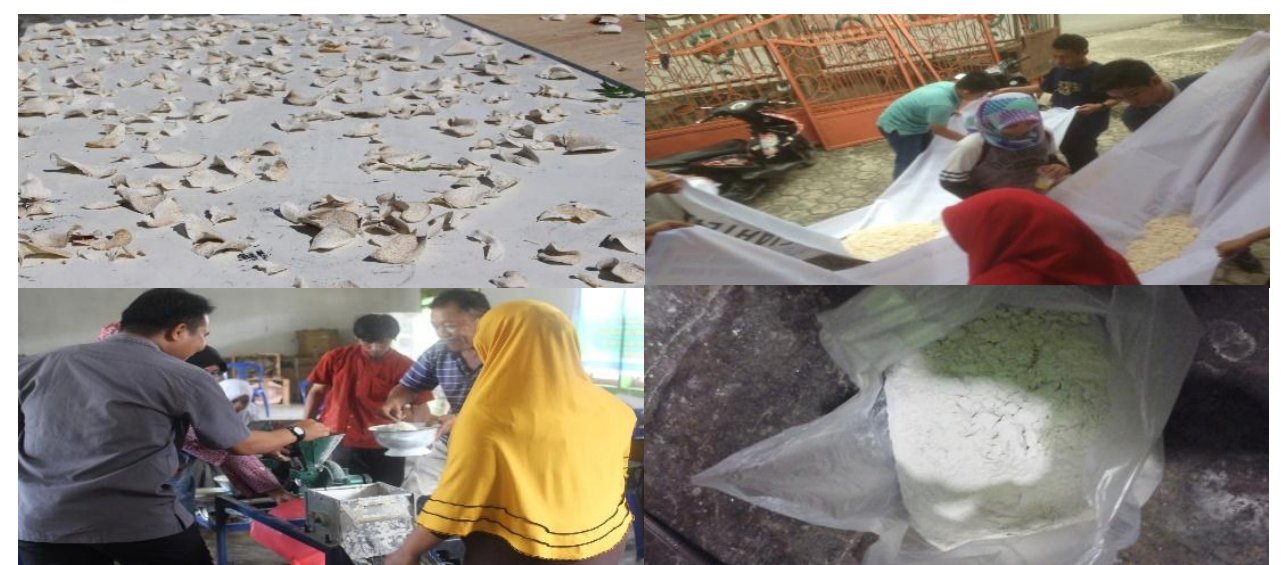

Gambar 7. Umbi bête hasil irisan yang telah dicuci dijemur dan digiling sehingga menjadi tepung Bete

\section{d. Tahap Pasca Pelaksanaan Pelatihan}

\section{1) Proses Pemasaran}

Para petani semakin semangat menanam lahan kosong dengan umbi bete, selama ini mereka menganggap umbi bete hanya dapat di konsumsi sebagai makanan pokok pengganti nasi, setelah adanya pelaksanaan

Pengabdian pada Masyarakat ini para petani merasa terbuka bahwa bete dapat dijadikan tepung sebagai pengganti terigu. Memberikan pelatihan penggunaan mesin/alat sederhana tentang pembuatan tepung bete, dan Memberikan pengetahuan tentang ilmu manajemen.

\section{2) Evaluasi}

Dalam kegiatan ini perguruan Tinggi dalam hal ini dosen berperan didalamnya sebagai pendamping lapangan dan narasumber untuk memotisi dan memfasilitasi suksesnya pelaksanaan kegiatan Pengabdian, memberikan introduksi ilmu pengetahuan manajemen serta sedikit memperkenalkan teknologi (IPTEK) yang lebih sederhana untuk digunakan dalam Pengabdian tersebut.

\section{3) Pendampingan}

Pendampingan bertujuan untuk mengevaluasi atas kekurangan kekurangan baik dalam segi pengetahuan maupun kekurangan dan kelebihan dalam membuat tepung bete. Pendampingan dilaksanakan setelah mitra ekonomi kreatif dan kelompok ibu PKK telah praktek langsung dalam pembuatan dan melihat langsung hasil tepung yang dibuat. Hal yang paling menarik adalah ibu PKK yang senang dan berharap tindak lanjut dari pembuatan tepung bete kearah yang lebih baik. Ibu PKK yang telah memiliki kreatif membuatan jajanan pagi sebagai bekal sarapan pagi sudah memiliki banyak ide untuk mengaplikasikan kreatifitas memanfaatkan bahan baku tepung bete tersebut. 


\section{KESIMPULAN}

Kesimpulan yang dapat diperoleh dari program pelaksanaan Pengabdian pada Masyarakat di Desa Lumbi - Lumbia ini Kecamatan Buko Selatan Kabupaten Banggai Kepulauan ini adalah:

a. Tingkat partisipasi Kelompok Mitra ekonomi bersama - sama masyarakat sangat antusiasi mengikuti kegiatan ini dan mereka menganggap program ini sangat memberikan dampak yang sangat positif secara khusus bagi kelompok mitra dan secara umum masyarakat dan ibu - ibu PKK dan aparat desa di desa Lumbi Lumbia Kecamatan Buko Selatan Banggai Kepulauan.

b. Hasil kegiatan Pengabdian pada Masyarakat diperoleh output kegiatan yaitu meningkatnya pengetahuan manajemen dan keterampilan masyarakat dalam mengolah dan membuat tepung bete dengan menggunakan mesin/teknologi mulai dari proses parut, press sampai pada penepungan menjadi tepung bete.

c. Selain sebagai makanan pokok di desa Lumbia - Lumbia bete/tepung bete dapat dijadikan sebagai subtitusi terigu.

d. Tingginya minta masyarakat yang ada di Desa Lumbia - Lumbia Kecamatan Buko Selatan Kapupaten Banggai kepulauan dalam dalam mengikuti semua rentetan kegiatan Pengabdian pada masyarakat diharapkan mendapatkan perhatian secara umum dari Pemerintah Kabupaten Banggai Kapulauan umumnya dan secara khusus bagi Pemerintah Desa Lumbi - Lumbia Kecamatan Buko Selatan Kabupaten Banggai Kepalauan, sehingga kedepannya kegiatan ini berkelanjutan pada tahap yang lebih positif terhadap peningkatan taraf hidup masyarakat dalam bidang ekonomi.

\section{UCAPAN TERIMAKASIH}

Tim pengabdian kemitraan masyarakat mengucapkan terima kasih kepada Direktur Litabmas Ditjen Kemenristek Dikti yang telah mendanai kegiatan pengabdian ini, semua pihak, instansi maupun perorangan yang telah mendukung serta mengarahkan sehingga kegiatan pengabdian ini terlaksana sesuai rencana.

\section{REFERENSI}

[1] Basu Swastha, dan T. Hani Handoko. (2008). Manajemen Pemasaran, Analisa Perilaku Konsumen. Edisi pertama, cet. ke4. BPFE. Yogyakarta.

[2] Welli, Dian. (2012). Pemanfaatan Umbi Talas Sebagai Bahan Subtitusi Tepung Terigu Dalam Pembuatan Cookies Yang Disuplementasi Dengan Kacang Hijau. Jurnal Matematika, Sains, dan Teknologi, Volume 13 Nomor 2, September 2012. Institut Pertanian Bogor

[3] Haruni, Ramadhani dan Yusuf. (2018). Kelompok Kreatif Tepung Bete Ibu - ibu PKK Desa Landonan Banggai Kepulauan. Prosiding The 7th URECOL 2018. Implementasi Perguruan Tinggi Dalam Desiminasi Penelitian Dan 
DIFUSI

Volume 2, No.1 Januari 2019

Pengabdian Kepada Masyarakat LPPM Stikes PKU Muhammadiyah. Surakartahal : hal $39-44$

[4] BPS. (2014). Indonesia (20102014). Jakarta.

[5] BPS. (2008). Statistik Indonesia 2007 - Produksi Umbi-umbian di Indonesia.. Jakarta.
[6] Suismono, (2001). Teknologi Pembuatan Tepung dan Pati Ubiubian Untuk Menunjang Ketahanan Pangan. Majalah Pangan. Puslitbang Bulog, Jakarta. Vol. X No. 37:37-49 